ks. Krzysztof Wilk

\title{
Biblia w ustach młodych. Konkurs biblijny
}

W piątek 11 IV 2003 uczniowie gimnazjów oraz szkół średnich Skawiny i okolic wzięli udział w konkursie recytatorskim. „Idź i głoś do tego ludu” $($ Iz 6, 9) - BIBLIA W USTACH MŁODYCH. Konkurs ten został zorganizowany przez Zespół Katolickich Szkół im. Jana Pawła II w Skawinie i był próbą zrozumienia, interpretacji oraz recytacji tekstów natchnionych a zaczerpniętych z Pisma Świętego. 
Po Mszy świętej w kościele Świętych Szymona i Judy Tadeusza w Skawinie w sali Pałacyku „Sokół” miało miejsce przesłuchanie 36 uczestników recytujących obszerne fragmenty wybierane zarówno ze Starego jak i Nowego Testamentu. Wśród recytowanych 3-minutowych tekstów licznie zgromadzona młodzież miała okazję wsłuchać się w treści Psalmów, Pieśni nad Pieśniami, Księgi Amosa, Hioba, Mądrości, fragmenty Ewangelii, listów Pawłowych, czy też Janowych, a także Apokalipsy. Powaga tekstów, ich głębia, a także wysoki poziom recytatorski przysporzyły wielu doznań zarówno artystycznych, jak i religijnych.

Komisję jurorów tworzyli Jadwiga Lesiak-Giżycka (aktorka Teatru Ludowego z Nowej Huty), Marta Tyrpa, ks. Piotr Studnicki z Wydziału Duszpasterstwa Dzieci i Młodzieży oraz ks. Adam Fołta - misjonarz z Brazylii. Nagrodzonych i wyróżnionych uczestników obdarował upominkami fundator nagród ks. proboszcz Leon Baran.

I miejsce - Bernadetta Aleksandrowicz z kl. IV, II miejsce - Bartłomiej Klimas kl. IV z Zespołu Szkół Techniczno-Ekonomicznych w Skawinie, III miejsce - Ramzi Bahlawan z Gimnazjum nr 2 w Skawinie. Wyróżniono także Klaudię Ziębę z Gimnazjum nr 1 w Skawinie, Magdalenę Hajto z Gimnazjum w Radziszowie i Katarzynę Luberdę z Zespołu Szkół Techniczno-Ekonomicznych w Skawinie. 